Abstracta Iranicacta Iranica

Revue bibliographique pour le domaine irano-aryen

Volume 32-33 | 2013

Comptes rendus des publications de 2009-2010

\title{
Leonard Lewisohn (ed.). Hafiz and The Religion of Love in Classical Persian Poetry
}

Anna Livia Beelaert

\section{OpenEdition}

1 Journals

Édition électronique

URL : http://journals.openedition.org/abstractairanica/40079

DOI : 10.4000/abstractairanica.40079

ISSN : 1961-960X

\section{Éditeur :}

CNRS (UMR 7528 Mondes iraniens et indiens), Éditions de l'IFRI

\section{Édition imprimée}

Date de publication : 1 décembre 2013

ISSN : 0240-8910

\section{Référence électronique}

Anna Livia Beelaert, «Leonard Lewisohn (ed.). Hafiz and The Religion of Love in Classical Persian Poetry ", Abstracta Iranica [En ligne], Volume 32-33 | 2013, document 8, mis en ligne le 01 juillet 2016, consulté le 01 octobre 2020. URL : http://journals.openedition.org/abstractairanica/40079; DOI : https://doi.org/10.4000/abstractairanica.40079

Ce document a été généré automatiquement le 1 octobre 2020.

Tous droits réservés 


\title{
Leonard Lewisohn (ed.). Hafiz and The Religion of Love in Classical Persian Poetry
}

\author{
Anna Livia Beelaert
}

\section{RÉFÉRENCE}

Leonard Lewisohn (ed.). Hafiz and The Religion of Love in Classical Persian Poetry. London/ New York, I.B. Tauris in association with Iran Heritage Foundation, 2010, xxvi + 330 p.

1 Ce volume résulte d'une conférence donnée à Exeter en 2007. À part un court avantpropos du regretté Peter Avery (décédé en 2008), et une première section grandiloquente par Lewisohn, qui donne un aperçu du contexte, 'Ḥâfiz in the Sociohistorical, Literary and Mystical Milieu of Medieval Persia' (p. 3-73), il contient neuf articles, de valeur très inégale, répartis entre trois sections. Dans l'ordre du livre: section II, 'Hāfiz and the School of Love in Classical Persian Poetry' : Husayn Ilahi Ghomshei, 'The Principles of the Religion of Love in Classical Persian Poetry' (p. 77-106); Ali Asghar Seyed-Gohrab, 'The Erotic Spirit: Love, Man and Satan in Ḥāfiz’s poetry' (p. 107-21) ; Leili Anvar, 'The Radiance of Epiphany: The Vision of Beauty and Love in Ḥāfiz's Poem of Pre-Eternity' (p. 123-39). Section III, 'țāfiz and the Persian Sufi Tradition': Charles-Henri de Fouchécour, 'Ḥâfiz and the Sufi' (p. 143-57); L. Lewisohn, 'The Religion of Love and the Puritans of Islam: Sufi Sources of Haâfiz's Anti-clericalism' (p. 159-96) ; Carl W. Ernst, 'Jalāl al-Dīn Davānī's Interpretation of Ḥāfiz’ (p. 197-210). Section IV, 'Ḥāfiz's Romantic Imagery and Language of Love' : Michael Barry, 'The Allegory of Drunkenness and the Theophany of the Beloved in Sixteenth-Century Illustrations of Hiâfiz’ (p. 213-226); James Morris, 'Transfiguring Love: Perspective Shifts and the Contextualization of Experience in the Ghazals of Hāfiz' (p. 227-50) ; Franklin Lewis, 'The Semiotic Horizons of Dawn in the Poetry of Ḥāfiz' (p. 251-77); Parvin Loloi, 'Ḥâfiz and the Language of Love in Nineteenth-Century English 
and American Poetry' (p. 279-94). Chaque article a ses propres notes en fin de document, mais la bibliographie est cumulative.

\section{AUTEURS}

\section{ANNA LIVIA BEELAERT}

Université libre de Bruxelles 